\title{
Assessment of The Role Annexin A1 in Pediatric with Bronchial Asthma at Zagazig University Hospitals \\ Hassan El-Banna Khedr ${ }^{1}$, Mohammed Sanad Nagiub ${ }^{1}$, Ayman Abd El Rahman Allam², Basma Abd El Hamid El-Said ${ }^{1}$
}

Departments of ${ }^{1}$ Pediatrics and ${ }^{2}$ Microbiology \& Immunology, Faculty of Medicine, Zagazig University, Egypt *Corresponding Author Name: Basma Abd El Hamid El-Said, Mobile : (+20)1024683929, Email: mosad8rashed@ gmail.com

\begin{abstract}
Background: Childhood asthma is a chronic inflammatory disorder of the airways in children characterized by interaction between many cells of the innate and adaptive immune systems that interact with epithelial cells to cause bronchial hyper-reactivity. Annexin A1 (ANXA1) is a glucocorticoid-induced protein with multiple functions in the regulation of inflammatory cell activation. ANXA1 has anti-inflammatory effects by stimulating inflammatory cell programmed cell death and prohibiting eicosanoid synthesis.

Objectives: The aim of the current work was to evaluate Annexin A1 levels in the blood of asthmatic patients and to evaluate the relationship between Annexin A1 levels and clinical profiles in asthma.

Patients and Methods: This case-control study included a total of 100 children, 80 of them were asthmatic and 20 were apparently healthy children, attending at Pediatric Department, Zagazig University Hospitals.

Results: There is a statistically significant higher annexin A1 among cases than control group $(3.3 \mathrm{ng} / \mathrm{ml} \mathrm{\&} 2.6 \mathrm{ng} / \mathrm{ml}$, respectively). There was a statistically significant difference between severity of bronchial asthma and serum Annexin A1 (higher annexin A1 values with increased severity of the disease). There was a statistically significant negative correlation between serum annexin A1 \& FEV1, FVC and PEF $(r=-0.27, p=0.01, r=-0.31, p=0.00$ and $r=-0.22$, $\mathrm{p}=0.05$ respectively). Serum IgE had statistically significant positive correlation with serum annexin A1 among studied cases $(\mathrm{r}=0.254 \mathrm{p}=0.023)$. ROC was done to detect a cutoff point, at which trying to detect asthma cases. We found that at a level of 2.65 we can diagnose asthmatic cases with sensitivity $70 \%$, specificity $65 \%$ with total accuracy $69 \%$.

Conclusion: It could be concluded that serum annexin A1 can be considered as a possible biomarker for diagnosis, grading of asthma severity.
\end{abstract}

Keywords: Assessment, Annexin A1 levels, Pediatric, Bronchial Asthma.

\section{INTRODUCTION}

Childhood asthma is a chronic inflammatory disorder of the airways in children ${ }^{(1)}$, characterized by interaction between many cells of the innate and adaptive immune systems that interact with epithelial cells to cause bronchial hyper-reactivity. Within the past few years, it has emerged as the most common incommunicable respiratory disease affecting children worldwide ${ }^{(2)}$

It manifests as recurrent attacks of wheezing, breathlessness, chest tightness, and coughing, particularly at night and in the early morning. These attacks are usually associated with variable airflow obstruction that is often reversible either spontaneously or with treatment. Childhood asthma prevalence worldwide is rising dramatically making it regarded as a major healthcare problem in children ${ }^{(3)}$.

The prevalence and morbidity of childhood asthma have been rising evidently during recent decades throughout the world ${ }^{(4)}$.

Annexin A1 (ANXA1) is a glucocorticoidinduced protein with multiple functions in the regulation of inflammatory cell activation. ANXA1 is a $37 \mathrm{kDa}$ protein that has been reported to have antiphospholipase activity following glucocorticoid induction and possesses a wide range of physiological and pathological functions. The biological effects of
ANXA1 differ based on intra- versus extracellular localization ${ }^{(5)}$.

ANXA1 has anti-inflammatory effects by stimulating inflammatory cell programmed cell death and prohibiting eicosanoid synthesis.

Lee et al. ${ }^{\left({ }^{(6)}\right.}$ identified the role of ANXA1 in bronchial asthma. They suggested that ANXA1 may be a potential marker and therapeutic target for asthma. They found that plasma ANXA1 levels were increased in asthmatic patients.

The reduced levels of lipoxin A4 (LXA4) and ANXA1 were reported in wheezy infants ${ }^{(7)}$. In addition, Ng et al. ${ }^{(8)}$ have shown that ANXA1 is associated with asthma development.

The aim of this work was to improve methods of diagnosis of patients with bronchial asthma.

The aim of the current work was to evaluate Annexin A1 levels in the blood of asthmatic patients and to evaluate the relationship between Annexin A1 levels and clinical profiles in asthma.

\section{PATIENTS AND METHODS}

This case-control study included a total of 100 children, 80 of them were asthmatic and 20 were apparently healthy children, attending at Pediatric Department, Zagazig University Hospitals. This study 
was conducted between September 2018 to August 2019.

The included children were divided into two groups; Cases group consisted of 80 asthmatic children who were subdivided into 4 subgroups $(20$ each $)$ : intermittent, mild, moderate, severe persistent, and Control group consisted of 20 age and sex matched apparently healthy children.

Inclusion criteria: All patients (5-14 years old) presented by wheezy chest and diagnosed as bronchial asthma by history, clinical picture and investigated by lab tests and chest x-ray.

Exclusion criteria: Age less than 5-year, dehydration, malignancies \& immune compromised patients, cystic fibrosis, active pulmonary tuberculosis, end stage liver or renal diseases, patient or relatives don't consent to participate in the study, health condition that would affect ability to give blood specimens.

\section{Ethical Consideration:}

Written Informed consent was taken from the parents of the children or their caregivers that participate in the study.

Approval for performing the study was obtained from Pediatric Department, Zagazig University Hospitals after taking Institutional Review Board (IRB) approval. This work has been carried out in accordance with The Code of Ethics of the World Medical Association (Declaration of Helsinki) for studies involving humans.

\section{All patients were subjected to:}

I. Patient classification: At the time of enrollment, the patient classified according to the GINA control status and treatment steps ${ }^{(9)}$.

\section{Thorough history taking and clinical examination}

- History: Detailed history taking include name, age, sex, associated comorbidities, consanguinity, family history of allergy, family history of smoking.

- Full general examination including vital signs, and body mass index (BMI) " $\mathrm{kg} / \mathrm{m}^{2}$ ".

III. Pulmonary function tests: Were performed by using the spirometry included: FEV1, FVC and PEF.

IV. Laboratory investigations:

A) Routine investigations including complete blood count (CBC): Kidney function tests: Liver function tests: ESR, CRP, and total immunoglobulin E (IgE): levels.
B) Special investigations:

Serum Annexin A1 level: measured by using ELISA kits from USCNK (Life Science Inc., PR China).

principle: The kit uses a double-antibody sandwich enzyme-linked immunosorbent assay (ELISA) to measure the level of human Annexin A1(ANXA1) in samples.

\section{Statistical Analysis}

Data were fed to the computer and analyzed using IBM SPSS software package version 22.0. Qualitative data were described using number and percent. Quantitative data were described using median (minimum and maximum) for non-parametric data and mean, standard deviation for parametric data after testing normality using Kolmogrov-Smirnov test. Significance of the obtained results was judged at the (0.05) level. P value < 0.05 was considered significant.

\section{Qualitative data:}

Chi-Square test for comparison of 2 or more groups. Monte Carlo test as correction for Chi-Square test when more than $25 \%$ of cells have count less than 5 in tables $(>2 * 2)$. Fischer Exact test was used as correction for Chi-Square test when more than $25 \%$ of cells have count less than 5 in $2 * 2$ tables. One Way ANOVA test was used to compare more than 2 independent groups with Post Hoc Tukey test to detect pair-wise comparison. Mann-Whitney U test was used to compare 2 independent groups. Kruskal Wallis test was used to compare more than 2 independent groups with Mann Whitney $\mathrm{U}$ test to detect pair-wise comparison. Receiver Operating Characteristic (ROC) curve analysis: The diagnostic performance of a test, or the accuracy of a test to discriminate diseased cases from non-diseased cases is evaluated using Receiver Operating Characteristic (ROC) curve analysis. Sensitivity and Specificity were detected from the curve and PPV,NPV and accuracy were calculated through cross tabulation

\section{RESULTS}

Table (1) shows that there is statistically significant difference between studied groups regarding consanguinity\& family history of smoking \&history of allergy. There is no statistically significant difference between studied groups regarding their age, sex and residence.

Table (2) demonstrates statistically significant increase inAEC, CRP\& serum IgE among cases than controls, there isstatistically significant increase inCRP among Sever asthma than (Intermittent asthma,Mild asthma and Moderate asthma). There is no statistically significant difference between cases and controls regarding ALT, AST, serum creatinine and $\mathrm{Hb}$.

Table (3) demonstrates that there is a statistically significant differance between severity of bronchial 
asthma and serum Annexin A1 (higher median annexin A1 values associated with increased severity of the disease).

Cases with severe bronchial asthma shows statistically significant difference while compared to other degrees of asthma severity.and there is a statistically significant increase in serum Annexin A1 between studied cases \& control groupswith higher median value associated with increased severity of the disease.

Table (4) illustrates that there is a statistically significant higher median annexin A1 among cases than control group ( $3.3 \& 2.6$, respectively).
Figure (1) shows that area under ROC curve for annexin A1 validity in differentiating cases \& control groups is good (0.708).

Table (5) illustrates that annexin A1 with cutoff point 2.65 and more obtained sensitivity $70 . \%$,specificity $65 \%$ with total accuracy $(69 \%)$.

Table (6) show that there is a statistically significant negative correlation between serum annexinA1 \&FEV1,FVC and PEF. SerumIgE\& CRP have statisticallysignificant positive correlation with serum annexin A1 among studied cases $(\mathrm{r}=0.254,0.269$ \& $\mathrm{p}=0.023,0.016)$.

Table (1): Demographic characteristics and history distribution among studied groups:

\begin{tabular}{|c|c|c|c|c|c|c|}
\hline & $\begin{array}{c}\text { Control } \\
\text { group } \\
\mathbf{N}=20(\%)\end{array}$ & $\begin{array}{c}\text { Intermittent } \\
\text { group } \\
\mathbf{N}=\mathbf{2 0}(\%)\end{array}$ & $\begin{array}{c}\text { Mild } \\
\text { group } \\
\mathbf{N}=20(\%)\end{array}$ & $\begin{array}{l}\text { Moderate } \\
\text { group } \\
\mathbf{N}=20(\%)\end{array}$ & $\begin{array}{c}\text { Severe } \\
\text { group } \\
\mathbf{N}=20 \%)\end{array}$ & $\begin{array}{c}\text { Test of } \\
\text { significance }\end{array}$ \\
\hline $\begin{array}{l}\text { Age/years } \\
\text { Mean } \pm \text { SD }\end{array}$ & $7.58 \pm 2.68$ & $8.27 \pm 2.62$ & $7.23 \pm 2.37$ & $8.58 \pm 2.34$ & $8.88 \pm 1.85$ & $\begin{array}{l}F=1.66 \\
P=0.17\end{array}$ \\
\hline $\begin{array}{l}\text { Sex } \\
\text { Male } \\
\text { Female } \\
\end{array}$ & $\begin{array}{c}15(75.0) \\
5(25.0)\end{array}$ & $\begin{array}{c}11(55.0) \\
9(45.0)\end{array}$ & $\begin{array}{c}16(80.0) \\
4(20.0)\end{array}$ & $\begin{array}{l}18(90.0) \\
2(20.0)\end{array}$ & $\begin{array}{c}17(85.0) \\
3(15.0)\end{array}$ & $\begin{array}{c}\mathrm{MC} \\
\mathrm{P}=0.8\end{array}$ \\
\hline $\begin{array}{l}\text { Residence } \\
\text { Urban } \\
\text { Rural }\end{array}$ & $\begin{array}{c}14(70.0) \\
6(30.0)\end{array}$ & $\begin{array}{c}16(80.0) \\
4(20.0)\end{array}$ & $\begin{array}{c}14(70.0) \\
6(30.0)\end{array}$ & $\begin{array}{c}15(75.0) \\
5(25.0)\end{array}$ & $\begin{array}{c}15(75.0) \\
5(25.0)\end{array}$ & $\begin{array}{l}\chi^{2}=0.73 \\
\mathrm{P}=0.95\end{array}$ \\
\hline Consanguinity & $4(20.0)$ & $14(70.0)$ & $12(60.0)$ & $14(70.0)$ & $14(70.0)$ & $\begin{array}{l}\chi^{2}=15.44 \\
\mathrm{P}=0.004^{*}\end{array}$ \\
\hline $\begin{array}{l}\text { Family history of } \\
\text { smoking }\end{array}$ & $6(30.0)$ & $13(65.0)$ & $13(65.0)$ & $15(75.0)$ & $12(60.0)$ & $\begin{array}{c}\chi^{2}=9.67 \\
\mathrm{P}=0.046^{*}\end{array}$ \\
\hline $\begin{array}{l}\text { Family history of } \\
\text { allergy }\end{array}$ & $16(80.0)$ & $3(15.0)$ & $8(40.0)$ & $6(30.0)$ & $5(25.0)$ & $\begin{array}{c}\mathrm{MC} \\
\mathrm{P}<0.001 *\end{array}$ \\
\hline
\end{tabular}

F:One Way ANOVA test MC: Monte-Carlo test $\chi^{2}$ :Chi-Square test

* Statistically significant $(\mathrm{p}<0.05)$

Table (2) : Laboratory results distribution among studied cases:

\begin{tabular}{|c|c|c|c|c|c|c|}
\hline & $\begin{array}{c}\text { Control } \\
\text { group } \\
\mathbf{N}=\mathbf{2 0}\end{array}$ & $\begin{array}{c}\text { Intermittent } \\
\text { group } \\
\mathbf{N}=\mathbf{2 0}\end{array}$ & $\begin{array}{l}\text { Mild } \\
\text { group } \\
\mathbf{N}=\mathbf{2 0}\end{array}$ & $\begin{array}{c}\text { Moderate } \\
\text { group } \\
\mathbf{N}=\mathbf{2 0}\end{array}$ & $\begin{array}{l}\text { Severe } \\
\text { group } \\
\mathbf{N}=20\end{array}$ & $\begin{array}{c}\text { Test of } \\
\text { significance }\end{array}$ \\
\hline $\begin{array}{c}\text { ALT } \\
\text { (IU/L) }\end{array}$ & $32.80 \pm 1.18$ & $31.35 \pm 5.64$ & $35.25 \pm 1.78$ & $34.65 \pm 5.85$ & $34.10 \pm 1.62$ & $\begin{array}{l}\mathrm{F}=0.48 \\
\mathrm{P}=0.75\end{array}$ \\
\hline $\begin{array}{c}\text { AST } \\
\text { (IU/L) }\end{array}$ & $26.15 \pm 6.84$ & $26.70 \pm 5.26$ & $25.35 \pm 5.42$ & $28.05 \pm 5.34$ & $28.70 \pm 5.76$ & $\begin{array}{l}\mathrm{F}=0.70 \\
\mathrm{P}=0.59\end{array}$ \\
\hline $\begin{array}{c}\text { Creatinine } \\
\text { (mgldL) }\end{array}$ & $0.59 \pm 0.14$ & $0.66 \pm 0.18$ & $0.72 \pm 0.16$ & $0.68 \pm 0.16$ & $0.66 \pm 0.16$ & $\begin{array}{l}\mathrm{F}=1.57 \\
\mathrm{P}=0.19\end{array}$ \\
\hline HB (g/dl) & $11.77 \pm 0.45$ & $11.88 \pm 0.60$ & $11.79 \pm 0.99$ & $11.99 \pm 0.99$ & $11.74 \pm 0.77$ & $\begin{array}{l}\mathrm{F}=0.42 \\
\mathrm{P}=0.79\end{array}$ \\
\hline AEC cells / $\mu \mathrm{l}$ & $69.35 \pm 7.67$ & $139.9 \pm 6.05$ & $267.25 \pm 50.35$ & $311.5 \pm 57.32$ & $414.10 \pm 100.82$ & $\begin{array}{l}\mathrm{F}=106.98 \\
\mathrm{P}<0.001^{*}\end{array}$ \\
\hline $\begin{array}{c}\text { CRP(mg/L) } \\
\text { Median }\end{array}$ & 0.9 & $\begin{array}{c}\text { (a) } \\
18.55^{\mathrm{AB}}\end{array}$ & $\begin{array}{c}\text { (b) } \\
16.12\end{array}$ & $\begin{array}{c}\text { (b) } \\
16.95\end{array}$ & $\begin{array}{c}(\mathrm{c}) \\
33.3\end{array}$ & $\begin{array}{l}\mathrm{KW} \\
\mathrm{P}<0.001 *\end{array}$ \\
\hline $\begin{array}{c}\text { IgE } \\
(\mathbf{I U} / \mathbf{m l})\end{array}$ & $45.57 \pm 4.09^{\mathrm{A}}$ & $100.20 \pm 21.49^{\mathrm{A}}$ & $222.49 \pm 8.02$ & $285.19 \pm 57.96$ & $444.28 \pm 82.71$ & $\begin{array}{l}\mathrm{F}=59.08 \\
\mathrm{P}<0.001 *\end{array}$ \\
\hline
\end{tabular}

Similar letters denote non-significant difference between groups

F:One Way ANOVA test * statistically significant (if $\mathrm{p}<0.05$ )

KW: Kruskal Wallis test 
Table (3): Comparison among studied groups regarding Annexin A1 distribution:

\begin{tabular}{|l|l|l|l|l|l|l|}
\hline & $\begin{array}{c}\text { Control } \\
\text { group } \\
\mathbf{N = 2 0}\end{array}$ & $\begin{array}{c}\text { Intermittent } \\
\text { group } \\
\mathbf{N}=\mathbf{2 0}\end{array}$ & $\begin{array}{c}\text { Mild } \\
\text { group } \\
\mathbf{N}=\mathbf{2 0}\end{array}$ & $\begin{array}{c}\text { Moderate } \\
\text { group } \\
\mathbf{N}=\mathbf{2 0}\end{array}$ & $\begin{array}{c}\text { Severe } \\
\text { group } \\
\mathbf{N}=\mathbf{2 0}\end{array}$ & $\begin{array}{c}\text { Test of } \\
\text { significance }\end{array}$ \\
\hline $\begin{array}{l}\text { Annexin A1 } \\
\text { (ng/ml) } \\
\text { Median }\end{array}$ & 2.6 & 2.95 & 3.0 & 3.45 & 3.95 & $\mathrm{KW}$ \\
\hline $\begin{array}{l}\text { Difference with intermittent } \\
\text { group }\end{array}$ & & $\mathrm{P} 1=0.65$ & $\mathrm{P} 1=0.95$ & $\mathrm{P} 1=0.02^{*}$ & \\
\hline Difference with mild group & & & $\mathrm{P} 2=0.42$ & $\mathrm{P} 2=0.002^{*}$ & \\
\hline $\begin{array}{l}\text { Difference with moderate } \\
\text { group }\end{array}$ & & & & $\mathrm{P} 3=0.036^{*}$ & \\
\hline $\begin{array}{l}\text { Comparison of each group } \\
\text { with control group }\end{array}$ & $\mathrm{p}=0.049^{*}$ & $\mathrm{p}=0.11$ & $\mathrm{p}=0.07$ & $\mathrm{p}<0.001^{*}$ & $\mathrm{P}=0.002^{*}$ \\
\hline
\end{tabular}

KW: Kruskal Wallis test *statistically significant ( if $\mathrm{p}<0.05$ ).

P1: difference between every group with intermittent group, P2:difference between mild group and every other group,p3: difference between moderate group and every other groups by Mann Whitney U test.

Table (4): Annexin A1 distribution among studied groups:

\begin{tabular}{|l|c|c|c|}
\hline & $\begin{array}{c}\text { Control } \\
\text { group }\end{array}$ & $\begin{array}{c}\text { Cases } \\
\text { group }\end{array}$ & Test of significance \\
\hline $\begin{array}{l}\text { Annexin A(ng/ml) } \\
\text { Median }\end{array}$ & 2.6 & 3.3 & $\begin{array}{c}\mathrm{z}=2.87 \\
\mathrm{p}=0.004 *\end{array}$ \\
\hline
\end{tabular}

Z:Mann Whitney U test * statistically significant

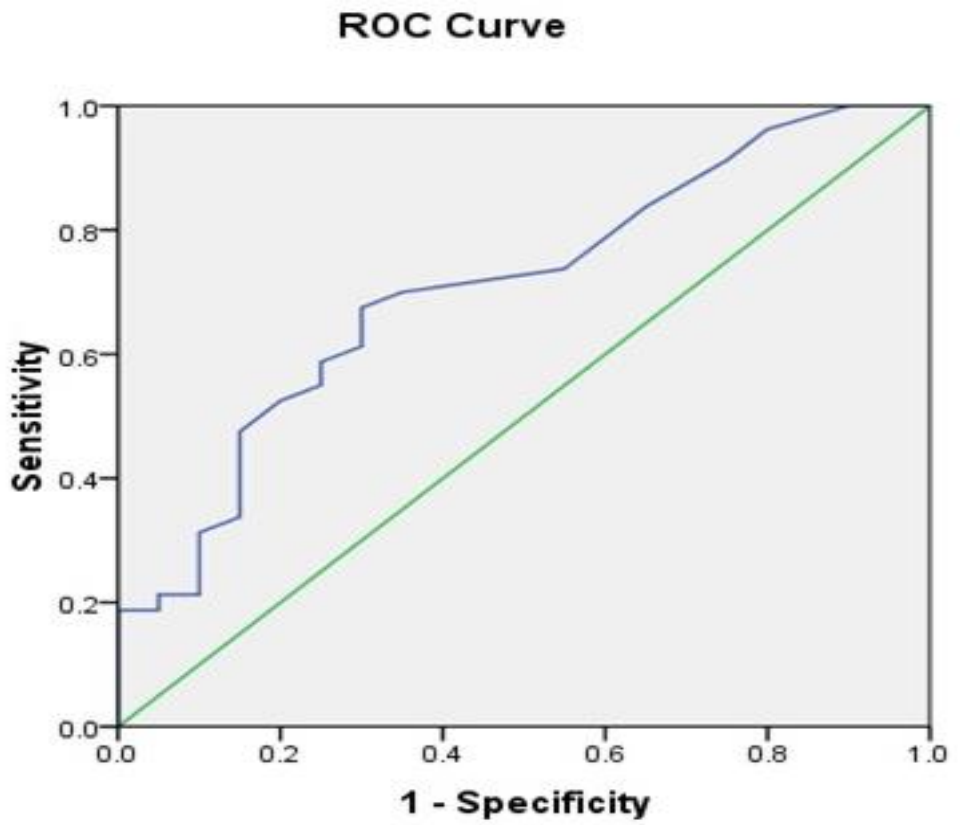

Figure (1): ROC curve for annexin A1 in differentiating cases and control groups.

Table (5): Statistical Performance of annexin A1 in differentiating cases and control groups:

\begin{tabular}{|c|c|c|c|c|c|c|c|}
\hline & $\begin{array}{c}\text { AUC } \\
(\mathbf{9 5 \%} \text { CI })\end{array}$ & $\begin{array}{c}\text { Cut off } \\
\text { point }\end{array}$ & Sensitivity & Specificity & PPV & NPV & Accuracy \\
\hline $\begin{array}{c}\text { Annexin } \\
\text { A1 }\end{array}$ & $\begin{array}{c}0.708 \\
(0.59-0.83)\end{array}$ & $\geq 2.65$ & $70.0 \%$ & $65.0 \%$ & $88.9 \%$ & $35.1 \%$ & $69.0 \%$ \\
\hline
\end{tabular}

AUC: Area Under curve PPV: Positive predictive value NPV: Negative predictive value 
Table (6): Correlation between Annexin A1 and pulmonary function tests and laboratory results among studied cases:

\begin{tabular}{|l|l|c|}
\hline \multirow{2}{*}{ FEV1 } & & Annexin.A1 \\
\hline \multirow{2}{*}{ FVC } & $\mathrm{R}$ & $-0.275^{*}$ \\
\cline { 2 - 3 } & $\mathrm{P}$ & 0.013 \\
\hline \multirow{2}{*}{ PEF } & $\mathrm{R}$ & $-0.319^{* * *}$ \\
\cline { 2 - 3 } & $\mathrm{P}$ & .0040 \\
\hline \multirow{2}{*}{ LFE } & $\mathrm{R}$ & $-0.220^{*}$ \\
\cline { 2 - 3 } & $\mathrm{P}$ & 0.050 \\
\hline \multirow{3}{*}{ AST } & $\mathrm{R}$ & $0.254^{*}$ \\
\cline { 2 - 3 } & $\mathrm{P}$ & .0230 \\
\hline \multirow{2}{*}{ Creatinine } & $\mathrm{R}$ & -0.079 \\
\cline { 2 - 3 } & $\mathrm{P}$ & .4840 \\
\hline \multirow{2}{*}{ HB } & $\mathrm{R}$ & 0.155 \\
\cline { 2 - 3 } & $\mathrm{P}$ & 0.171 \\
\hline \multirow{2}{*}{ AEC.Cells.mm3 } & $\mathrm{R}$ & -0.093 \\
\cline { 2 - 3 } & $\mathrm{P}$ & 0.414 \\
\hline \multirow{2}{*}{ CRP } & $\mathrm{R}$ & -0.041 \\
\cline { 2 - 3 } & $\mathrm{P}$ & 0.716 \\
\cline { 2 - 3 } & $\mathrm{R}$ & 0.197 \\
\hline & $\mathrm{P}$ & 0.080 \\
\cline { 2 - 3 } & $\mathrm{R}$ & $0.269^{*}$ \\
\hline
\end{tabular}

R: Spearman correlation co-efficient * statistically significant $(\mathrm{p}<0.05)$

\section{DISCUSSION}

The current study showed that there is a statistically significant higher annexin A1 among cases than control group $(3.3 \mathrm{ng} / \mathrm{ml}$ \& $2.6 \mathrm{ng} / \mathrm{ml}$, respectively).

These results agree with Gungor $\boldsymbol{e t}$ al. ${ }^{(10)}$ who reported that ANXA1 has compensatory antiinflammatory effects in asthma.

This is also in agreement with Lee et al. ${ }^{(\boldsymbol{6})}$ who revealed plasma ANXA1 levels were increased in asthmatic patients compared with healthy controls.

Bandeira-Melo et al. ${ }^{(11)}$ used peptide Ac2-26 (derivative from ANXA1) as an antiallergic agent for rats sensitized via ovalbumin administration to the pleural cavity. This peptide inhibited mast cell degranulation and neutrophil and eosinophil recruitment, and it prevented the release of histamines and eotaxins which are precursor mediators. This condition suggests that derivatives of ANXA1 can be used in the presence of allergic inflammation ${ }^{(12)}$.

This is totally in contrast to the results reported by Gungor et al. (10) where ANXA1 levels were compared between children with wheezing and controls. It was found to be markedly lower in the wheezing group $(14.45 \pm 3.26 \mathrm{ng} / \mathrm{ml})$ than in the control group $(16.40 \pm 1.94 \mathrm{ng} / \mathrm{ml})$.

Our study showed that there is a statistically significant difference between severity of bronchial asthma and serum Annexin A1 (higher annexin A1 values with increased severity of the disease).
These results agree with with Planagumà $\boldsymbol{e t} \boldsymbol{a l}$. (7) and Levy et al. ${ }^{(13)}$ who found that cases with sever bronchial asthma showed statistically significant increase while compared to other degrees of asthma severity.

The current study demonstrated that there is a statistically significant negative correlation between serum annexin A1 \& FEV1, FVC and PEF(r $=-0.27$, $\mathrm{p}=0.01, \mathrm{r}=-0.31, \mathrm{p}=0.00$ and $\mathrm{r}=-0.22, \mathrm{p}=0.05$ respectively).

This agree with Lee $\boldsymbol{e t} \boldsymbol{a l} .{ }^{(\boldsymbol{6})}$ who found that, Plasma ANXA1 levels were significantly negatively correlated with forced expiratory volume (FEV1\%) ( $\mathrm{r}$ $=-0.191, \mathrm{p}=0.033)$ and forced vital capacity $(\mathrm{FVC})$, $(\mathrm{r}=-0.202, \mathrm{p}=0.024)$.

Our study showed that, serum IgE had statistically significant positive correlation with serum annexin A1 among studied cases $(\mathrm{r}=0.254 \mathrm{p}=0.023)$.

This agree with Parisi et al. ${ }^{(14)}$ who stated that there was statistically significant positive correlation between serum annexin $\mathrm{A} 1$ and serum $\operatorname{IgE}(\mathrm{r}=0.254$ $\mathrm{p}=0.023)$.

In the current study, ROC was done to detect a cutoff point, at which we tried to detect asthma cases. We have found that at a level of 2.65 we can diagnose asthmatic cases with sensitivity $70 \%$, specificity $65 \%$ with total accuracy $69 \%$.

Lee et $\boldsymbol{a l}$. (6) found that sensitivity and specificity of Annexin-A1 in detection of asthma using receiver operating characteristic curve (ROC) were $68 \%$ and $99.68 \%$, resp.They concluded that ANXA1 may be a potential marker for asthma.

\section{CONCLUSION}

It could be concluded that serum annexin A1 can be considered as a possible biomarker for diagnosis, grading of asthma severity.

\section{Financial support and sponsorship: Nil. Conflict of interest: Nil.}

\section{REFERENCES}

1. Ma Y, Liua X, Wei $Z$ et al. (2014): The expression of a novel anti- inflammatory cytokine IL-35 and its possible significance in childhood asthma. Immunol Lett., 162:11-17.

2. Lambrecht B, Hammad H (2015): The immunology of asthma. Nat Immunol., 16:45-56.

3. Yangzong Y, Shi Z, Nafstad $P$ et al. (2012): The prevalence of childhood asthma in China: a systematic review. BMC Public Health, 12:860-66.

4. Hansen T, Evjenth B, Holt J (2013):Increasing prevalence of asthma, allergic rhinoconjunctivitis and eczema among schoolchildren: three surveys during the period 1985-2008. Acta Paediatr., 102(1):47-52.

5. Guo C, Liu S, Sun M (2013): Potential role of Anxa1 in cancer. Future Oncol., 9(11): 1773-93.

6. Lee S, Lee P, Kim B et al. (2018): Annexin A1 in plasma from patients with bronchial asthma: its association with lung function. BMC Pulmonary Medicine, 18(1): 1-5. 
7. Planagumà $\mathrm{A}$, Kazani $\mathrm{S}$, Marigowda $\mathrm{G}$ et al. (2008): Airway lipoxin A4 generation and lipoxin A4 receptor expression are decreased in severe asthma. Am J Respir Crit Care Med., 178(6): 574-82.

8. Ng F, Wong K, Guan S et al. (2011): Annexin-1deficient mice exhibit spontaneous airway hyperresponsiveness and exacerbated allergen-specific antibody responses in a mouse model of asthma. Clinical \& Experimental Allergy, 41(12): 1793-1803.

9. GINA (2017): Global Initiative for Asthma. https://ginasthma.org/wp-

content/uploads/2019/06/GINA-2019-main-reportJune-2019-wms.pdf

10. Gungor H, Tahan F, Gokahmetoglu S et al. (2014): Decreased levels of lipoxin A4 and annexin A1 in wheezy infants. International Archives of Allergy and Immunology, 163(3): 193-197.
11. Bandeira-Melo C, Bonavita A, Diaz B et al. (2005): A novel effect for annexin 1-derived peptide ac2-26: reduction of allergic inflammation in the rat. Journal of Pharmacology and Experimental Therapeutics, 313(3): 1416-1422.

12. Wang L, Li W, Xu Y et al. (2011): Annexin 1-derived peptide Ac2-26 inhibits eosinophil recruitment in vivo via decreasing prostaglandin D2. International Archives of Allergy and Immunology, 154(2): 137-148.

13. Levy B, Bonnans C, Silverman E et al. (2005): Diminished lipoxin biosynthesis in severe asthma. Am J Respir Crit Care Med., 172(7):824-30.

14. Parisi J, Corrêa M, Gil C (2019): Lack of Endogenous Annexin A1 Increases Mast Cell Activation and Exacerbates Experimental Atopic Dermatitis. Cells, 8(1): 51-56. 